\title{
The Effect of Light on Daily Life Activities and Sleep in Patients with Alzheimer's Disease
}

\section{Alzheimer Hastalarında Ișığın Günlük Yașam Aktiviteleri ve Uyku Üzerindeki Etkisi}

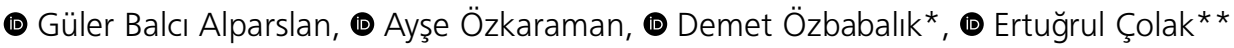 \\ Eskişehir Osmangazi University Faculty of Health Science, Department of Nursing, Eskişehir, Turkey \\ *Eskişehir Acıbadem Hospital, Clinic of Neurology, Eskişehir, Turkey \\ **Eskişehir Osmangazi University Faculty of Medicine, Department of Biostatistic, Eskişehir, Turkey
}

\begin{abstract}
Objective: The aim of this study is to identify the effect of the light on activities of daily living and sleep in patients with Alzheimer's disease. Materials and Methods: In this study, the actigraph devices, sleep and light application forms and Barthel Daily Life Activities forms were used. The study was conducted in an Alzheimer care center in Eskişehir. At first, all of the forms were filled and the wrist actigraphies were worned. The patients with actigraphies were monitored one week before the light application. During the second week, the light was applied to patients and the actigraphies were recorded. Actigraphies were recorded total of 4 weeks for each patient (average 30 minutes per day, around 3.00 $\mathrm{pm}$, from $50 \mathrm{~cm}$ distance and 1000 lux over 7 days). The sleep and light application forms were filled. After than, actigraphies of patients were recorded over the third and fourth weeks.

Results: There was a significant difference for the sleep durations $(p<0.05)$ and the inactivity status $(p=<0.001)$ in patients with Alzheimer's disease who were applied light, however no significant difference was found for the intensity of activities ( $p>0.05$ ).

Conclusion: It was determined that the light has no effect on the intensity of activities, though it extended the periods of inactivity and sleep.

Keywords: Alzheimer's disease, non-pharmacological therapy, nursing, sleep disorders
\end{abstract}

Öz

Amaç: Bu çalışmanın amacı, Alzheimer hastalarında ışığın günlük yaşam aktiviteleri ve uyku üzerindeki etkisini belirlemektir.

Gereç ve Yöntem: Çalışmada, aktigrafi cihazları, uyku ve ışık uygulama formları, Barthel Günlük Yaşam Aktiviteleri formları kullanılmışır. Çalışma, Eskişehir' de bir Alzheimer bakım merkezinde, yapılmıştır. Öncelikle tüm formlar doldurulmuş ve aktigrafiler bileklerine takılmışıır. Işık uygulamadan bir hafta önce hastalar aktigrafi ile izlenmiştir. Ikinci hafta, hastalara bir hafta ışık uygulanmış ve aktigrafi kaydı alınmıştır. Bir hastanın toplamda dört hafta boyunca aktigrafi kaydı alınmıştır (7 gün boyunca günde ortalama 30 dakika saat 15 civarında, $50 \mathrm{~cm}$ uzaklıktan ve 1000 lüks). Uyku ve ışık uygulama formları doldurulmuştur. Daha sonra üçüncü ve dördüncü haftalar boyunca hastaların aktigrafi kaydı alınmıştır.

Bulgular: Işık uygulanan alzheimerli hastaların uyku süreleri arasında anlamlı fark $(p<0,05)$ ve hastaların inaktivite durumları karşılaştırıldığında da anlamlı fark bulunmuş $(p=<0,001)$ ancak hastaların aktivite şiddetinde anlamlı bir fark bulunmamıştır $(p>0,05)$.

Sonuç: Yoğun aktivitede ışığın etkisinin olmadığı, inaktivite periyotlarını uzattığı uyku periyotlarını uzattığı belirlenmiştir.

Anahtar Kelimeler: Alzheimer hastalığı, ilaç dışı uygulama, hemşirelik, uyku bozuklukları

\section{Introduction}

Alzheimer's disease (AD) is a progressive disease setting in which there are losses in cognitive and functional abilities, basic life activities are not carried out along with progressing and individuals become dependent on the support of others. Accordingly, AD patients are hospitalised in nursing homes even in early periods of the disease (1-3).
Since there is not a definite treatment for $A D$, the period after the final diagnosis requires an effective team approach. The goal of the team is to maintain an independent life for the patient as long as possible, retard the progression of the disease, prevent the complications, and increase the quality of life of both the patients and their family (4). On the other hand, the basic purpose of nursing is to help individuals who are unable to sustain their basic life activities. In order for

Address for Correspondence/Yazışma Adresi: Güler Balcı Alparslan Prof, Eskişehir Osmangazi University Faculty of Health Science, Department of Nursing, Eskişehir, Turkey Phone: +90 5358627069 E-mail: gbalci80@hotmail.com ORCID-ID: orcid.org/0000-0003-3734-3843

Received/Geliş Tarihi: 03.04.2019 Accepted/Kabul Tarihi: 11.08.2019

${ }^{\circ}$ Copyright 2018 by Turkish Sleep Medicine Society / Journal of Turkish Sleep Medicine published by Galenos Publishing House. 
individuals to maintain their basic life, such main physiological needs as air, water, nourishment, excretion and sleep should be evenly met. If any of these needs is not timely met, several problems arise $(5,6)$.

Sleep, one of the basic life activities, is of importance for maintaining neuronal health. It has been identified in a study of Benedict et al. (7) thatmales over 70 years of age with sleep disorder have 1.33 times higher risk in terms of dementia and $A D$ than those over 70 without sleep disorder. It has been found out in another study that patients over 75 years of age reporting shortened sleep duration have $75 \%$ higher risk in terms of dementia and 2 times higher risk with regard to $A D$ (8). Sleep disorders are frequently seen among patients with AD (9). Sleep disorder seen in $40 \%$ of patients with dementia causes physical and psychosocial stress for both patients and caregivers and it is an important reason for the hospitalising of patients into nursing homes in the long term (9). Patients with dementia have such sleep disorders as frequently waking up while sleeping, having difficulties while getting off to sleep, increase in non-rapid eye movement phase, decrease in slowwave sleep, and falling asleep during daytime (9). For all these reasons, it is necessary to primarily deal with sleep disorders in order to prevent the development of and treat the AD in the elderly.

Among the primary treatment methods applied for treating sleep disorders and increasing sleep quality are pharmacologic applications, cognitive-behavioural therapies, and psychological/circadian therapies. The benzodiazepines, nonbenzodiazepines, tricyclic antidepressants, and antipsychotics which all have sedative effect treatsleep disorders in short term; however, in the long term and especially in the elderly, they cause anticholinergic effects, higher risk of falling down and having fractures, and increased addiction. That being the case, drug therapies should be used in cases where behavioural treatment methods fall short. Cognitive-behavioural therapies are particularly recommended for patients with dementia to regulate the sleep environment and duration, decrease daytime sleep, and eliminate sleep disorders (9).

It has been reported that the phototherapy, one of the methods among psychological/circadian therapies, decrease sleep disrupting at nights early waking-up in the mornings, shortens the duration of falling asleep, and decreases the frequency of daytime sleeps in elder patients with dementia (10). The phototherapy carried out during daytime supresses the melatonin secretion from hypophysis by stimulating photoreceptors and suprachiasmatic nucleus through retina and therefore ensures that melatonin secretion is done at nights by regulating circadian rhythm (11). By regulating circadian rhythm through phototherapy, pathologic phase delay is corrected (12). In a study of Akyar and Akdemir (13), it has been identified that the sleep quality of geriatric patients has increased after the phototherapy in a density of 10.000 lux. According to Gammack (11), the phototherapy is effective although there is not a specified optimal protocol to treat the sleep disorder of the patients with dementia and chronic insomnia and without seasonal depression. In a study carried out to examine the effect of phototherapy on eyes, it has been determined that the phototherapy applied for 1250 hours in 5 years in a density of 10.000 lux does not have a major adverse effect on eyes (14). On the other hand, Labbate et al. (15) have found out that the phototherapy applied on eyes has limited visual adverse effects on patients.

It is remarkable that phototherapy is applied to increase the sleep quality of geriatric patients; there are few studies in the literature researching the interaction between phototherapy and sleep quality (13); phototherapy is not routinely used to treat the sleep disorders of patients with $A D$, and there are no studies in the literature about this topic.

In accordance with this knowledge, the problems arising from sleep disorder in patients with AD are of much importance due to the adverse effects of pharmacologic treatment methods. The use of phototherapy by the nurses who effectively applynonpharmacologic methods among health professionals is of much importance to decrease the sleep disorders and increase the sleep quality of the patients with AD. For this reason, the purpose of the study that will be carried out in the future will be to treat sleep disorders frequently seen in patients with $A D$ through a cost-efficient and non-pharmacologic method with less adverse effects.

The purpose of this study is to determine the effect of light on daily-life activities and sleep of the patients with $A D$.

\section{Materials and Methods}

This experimental study has been carried out in order to identify the effect of light on daily-life activities and sleep of the patients with AD. This study was supported by Eskişehir Osmangazi University Commission of Scientific Research.

The nursing home where the study has been carried out provides daytime nursingcare with beds for patients with AD. The universe of the study is the patients receiving nursing care in the nursing home. The sample of the study is the patients compatible with the inclusion criteria.

\section{Inclusion Criteria}

Having a sense for light (patients could have contact lenses/ glasses),

Having a sense of hearing,

Not having proliferative diabetic retinopathy and macular degeneration,

No change in drug therapy for the last 3 months.

\section{Exclusion Criteria}

The change in above criteria during the study has been accepted as an exclusion criterion.

\section{Data Collection Form and Implication}

The data have been collected through actigraphy devices, Patient Descriptive Characteristics Form, Light Application Forms, and Barthel Instrumental Activities of Daily Living Index (Barthel ADL).

The use of actigraphy became widespread after the American Sleep Association decided the device could be used within "Sleep Studies" in 1995 (16). Actigraphy is a small, light, 
mobile and watch-like device that measures sleep-wake cycle in children and adolescents, senses motor activities with precision, is used by wearing on ankle or wrist, and digitally records and stores relaxation and activity patterns. This device which records activities depending on the capacity of its micro-sensors and worn on the wrist of non-dominant handis used to track daily sleep patterns along with long-term follow-up of sleep patterns in patients with sleep disorders. Except sleep, nap analysis during daytime is also possible through the device $(10,16,17)$. Along with evaluation of sleep-patterns, actigraphymakes its analyses by also sensing light, daily activities and the intensity of these activities. The relevant devices have been imported for the study.

Patient Descriptive Characteristics Form has been developed by the researchers considering the knowledge in the literature and includes socio-demographic features of the patients and information about the disease and the relevant treatment procedure $(10,13,17-20)$.

The Light Application Form has been developed by the researchers with reference to the knowledge in the literature and is composed of adverse effects of light phototherapy and is daily filled in $(13,15)$. The information about such adverse effects as xerophthalmia, stinging and burning in the eyes, redness on the face or arms, tenderness of the skin, irritability, headache, nausea, vomiting is included in the form.

Barthel Instrumental Activities of Daily Living Index (Barthel ADL) was developed by Barthel and Mahoney in 1965. Barthel $A D L$ is a kind of detailed, objective, easy-to-apply and simple scale that researches the cause and effect relation and evaluates all the stages of daily-life activities. The scoring is between 0 and 100 and the score between $0-20$ means "fully dependent", 21-61 means "severely dependent", 62-90 means "moderately dependent", 91-99 means "mildly dependent", and 100 means "fully independent".

As the source of light, the application of the density of 20003000 lux for 1 or 2 hours is adequate for stimulating circadian rhythm to resolve sleep disorders and increase the sleep quality $(10,13,18-20)$. Depending on this knowledge, the source of light will be placed into the patients' environment. The white source of light is 160 watts and when the distance between the light and the patient is set up as $58.42 \mathrm{~cm}$ (23 inches), it equals to the density of 10.000 lux (the model of the lamp: Apollo bright lite IVIM: 2-Sylvania 55w FT55DL/841 marka/ UltraluxR, 15" distance, 10.000 lux) (21).

\section{Data Collection}

After the necessary approvals has been received, patients conforming to the inclusion criteria have been determined. Since there has been 2 actigraphy devices, 2 patients have been included in the study at the same time and after a month's follow-up, other two patients have been included into the study.

The data have been collected in three stages. A patient has been applied phototherapy for a week and the actigraphy device has been applied for three weeks.

The first stage includes seven days before the application of phototherapy and the following implementations have been applied; Patient Descriptive Characteristics Form and Barthel activities of daily living have been filled in for each patient.

Actigraphy device has been worn to the patients and they have been told to wear the device for four weeks. The follow-up procedure has been started immediately. The healthcare staff has also been told that the patient should wear the device including bath times.

The duration of the second stage is seven days and includes the stages below:

Patients are invited to the room every day between 15:00 and 15:30 where the source of light is located and they have sat down around a table within the same distance to the light source. They have been exposed to light for 30 minutes while having a chat.

The patients have been exposed to 10.000 lux density light for 30 minutes within a distance of $58-60 \mathrm{~cm}$.

The Light Application Form has been filled in everyday to take down the adverse effects patients have experienced.

The third stage includes the following stages: Patients have been followed up for two weeks with the actigraphy device is on their wrists.

The necessary approval from the Ethics Committee of Eskişehir Osmangazi University (2016-06) and the Institution has been granted before the study along with the informed consent of the patients or their relatives.

\section{Statistical Analysis}

The data have been analysed through a special software of the actigraphy device and other software about statistics.

\section{Results}

Of the patients with $A D, 53.3 \%$ has been over 80 years of age; $40.0 \%$ is between $65-80$ age ranges; $40.0 \%$ is female; $53.3 \%$ is elementary school graduate; $60.0 \%$ is single and $40.0 \%$ is housewife.

Along with Alzheimer's, $46.7 \%$ of the patients have cardiovascular; $20.1 \%$ has endocrine, and $6.7 \%$ has respiratory system disorders. It has been identified that in terms of the duration of nursing, $46.7 \%$ has received care support for $1-2$ years; $26.8 \%$ for less than a year, and $26.8 \%$ for more than two years. When the geriatric patients have been evaluated in terms of daily life activities, it has been concluded that $40.0 \%$ is moderately dependent, $26.7 \%$ is severely dependent, $26.7 \%$ is independent, and $6.7 \%$ is mildly dependent (Table 1 ).

A significantdifference $(p<0.05)$ has been found between the sleep duration of the phototherapy applied $A D$ patients and this difference is between the first and fourth weeks (Table 2). When the inactivity performance of the patients have been compared, a statistical significance $(p<0.001)$ has been found between both the first and third weeks and the first and fourth weeks (Table 3).

Except these results, no significant difference has been found between activity intensity of the patients ( $p>0.05$ ) (Table 4$)$.

\section{Discussion}

According to the results of the study, it has been concluded that phototherapy has not affected the activity intensity of the 


\begin{tabular}{|c|c|c|}
\hline Characteristics $n=15$ & Number & $\%$ \\
\hline \multicolumn{3}{|l|}{ Age } \\
\hline Less than 65 & 1 & 6.7 \\
\hline $65-80$ & 6 & 40 \\
\hline Over 80 & 8 & 53.3 \\
\hline \multicolumn{3}{|l|}{ Gender } \\
\hline Female & 6 & 40 \\
\hline Male & 9 & 60 \\
\hline \multicolumn{3}{|l|}{ Educational background } \\
\hline Elementary school or lower & 7 & 46.7 \\
\hline Higher than elementary school & 8 & 53.3 \\
\hline \multicolumn{3}{|l|}{ Marital status } \\
\hline Married & 6 & 40 \\
\hline Single & 9 & 60 \\
\hline \multicolumn{3}{|l|}{ Profession } \\
\hline Officer/worker & 4 & 26.8 \\
\hline Housewife & 6 & 40 \\
\hline Self-employed & 5 & 33.5 \\
\hline \multicolumn{3}{|l|}{ Other diagnosed diseases } \\
\hline Cardiovascular & 7 & 46.7 \\
\hline Respiratory & 1 & 6.7 \\
\hline Endocrine & 3 & 20.1 \\
\hline Other & 7 & 46.7 \\
\hline \multicolumn{3}{|l|}{ The duration of support (year) } \\
\hline Less than 1 & 4 & 26.8 \\
\hline $1-2$ & 7 & 46.7 \\
\hline More than 2 & 4 & 26.8 \\
\hline \multicolumn{3}{|l|}{ Barthel ADL dependency status } \\
\hline Severely & 4 & 26.7 \\
\hline Moderately & 6 & 40 \\
\hline Mildly & 1 & 6.7 \\
\hline Independent & 4 & 26.7 \\
\hline
\end{tabular}

patients with $A D$ although it has increased the daily activities and sleep duration. When other studies limited in number have been analysed, it has been identified that Figueiro et al. (19) has also determined that phototherapy has increased the sleep duration. It has been reported in another study that the sleep quality of geriatric patients whom phototherapy, with a density of 2500 lux, have been applied has increased (20). Some studies point out that the application of phototherapy with a density of 2000-3000 lux for 1-2 hours is adequate for stimulating circadian rhythm with the aim of resolving sleep disorders and increasing the quality of sleep $(10,13,18-20)$.

Van der Ploeg et al. (22) have remarked that phototherapy has positive effects on sleep pattern. Forbes et al. (23) have stated that there are studies in the literature pointing out phototherapy has positive effects on both sleep and daily life activities although they underline the need for more studies to support this hypothesis. Dowling et al. (24) have identified that application of melatonin hormone along with phototherapy regulates sleep quality and daily activities. Burns et al. (25) and Riemersma-van der Lek et al. (26) have concluded that physical activities are regulated through phototherapy. Burns et al. (25) have pointed out that along with decreasing of the agitation, phototherapy has also regulated the physical activities of the elderly.

Depending upon the changes in neurological system, patients diagnosed with Alzhemier's disease sometimes experience agitation, sleep disorder and night insomnia along with aimless walking. At the end of our study, we have concluded that thanks to the phototherapy applied during daytime, circadian rhythm is regulated; patients carry out their daily physical activitiesby keeping awake during daytime and effectively sleep at nights. This condition could increase the participation of $A D$ patients into daily life activities by decreasing daytime sleeps. As is well known, the important thing in the care for patients with $A D$ is supporting the mental and physical state of patients. Thanks to the phototherapy, both the physical and mental state of the patients are supported and by this way patients will have the opportunity to participate in daily social activities and their quality of life will increase. Prolonged sleep duration and increased daily physical activities will also positively affect

\begin{tabular}{|c|c|c|c|c|}
\hline Group (week) & $x$ & $\pm S$ & $F$ & $p^{*}$ \\
\hline 1. (Avg. of $1-7^{\text {th }}$ days) & 6.395 & 2.142 & \multirow{4}{*}{5.651} & \multirow{4}{*}{0.002} \\
\hline 2. (Avg. of $8-14^{\text {th }}$ days) & 7.795 & 2.019 & & \\
\hline 3. (Avg. of $15-21^{\text {st }}$ days) & 7.595 & 2.501 & & \\
\hline 4. (Avg. of $22-28^{\text {th }}$ days) & 8.092 & 2.891 & & \\
\hline Group comparisons & $\mathbf{t}$ & & $\mathbf{p}^{* *}$ & \\
\hline $1-2$ & 3.161 & & 0.002 & \\
\hline $1-3$ & 2.709 & & 0.009 & \\
\hline $1-4$ & 3.830 & & $<0.001$ & \\
\hline
\end{tabular}


Balcı Alparslan et al.

The Effect of Light on Daily Life Activities and Sleep

\begin{tabular}{|c|c|c|c|c|}
\hline Group (week) & $x$ & $\pm S$ & Median (25-75) percentage & $\mathbf{p}^{*}$ \\
\hline 1. (Avg. of $1-7^{\text {th }}$ days) & 8.933 & 12.227 & $5.000(2.250-7.500)$ & \multirow{3}{*}{$<0.001$} \\
\hline 3. (Avg. of $15-21^{\text {st }}$ days) & 2.867 & 2.973 & $2.000(1.000-3.000)$ & \\
\hline 4. (Avg. of $22-28^{\text {th }}$ days) & 2.667 & 2.526 & $2.000(1.000-3.000)$ & \\
\hline Group comparisons & \multicolumn{2}{|l|}{$q$} & \multicolumn{2}{|l|}{$\mathbf{p}^{* *}$} \\
\hline $1-3$ & \multicolumn{2}{|l|}{4.200} & \multicolumn{2}{|l|}{$<0.001$} \\
\hline $\begin{array}{l}\text { * One-Way ANOVA } \\
\text { **Tukey test }\end{array}$ & & & & \\
\hline
\end{tabular}

\begin{tabular}{|l|l|l|l|l|}
\hline Table 4. Activity intensity & $\mathrm{X}$ & $\pm \mathrm{S}$ & Median (25-75) percentage \\
\hline Group (week) & 96.550 & 54.321 & $93.570(58.178-136.842)$ \\
\hline 1. (Avg. of 1-7th days) & 90.987 & 47.118 & $73.550(57.360-131.760)$ \\
\hline 2. (Avg. of 8-14th days) & 96.941 & 58.518 & $87.030(43.418-132.285)$ \\
\hline 3. (Avg. of 15-21 st days) & 92.861 & 53.143 & $85.500(45.935-134.732)$ \\
\hline 4. (Avg. of 22-28th days) & & & 0.998 \\
\hline *Friedman Variance Analysis & \multicolumn{3}{|l|}{} \\
\hline
\end{tabular}

the life quality of care givers and the quality of care given to patients.

\section{Study Limitations}

The study has been carried out with only two actiwatchdevices due to problems about the devices and the budgetary limitations of the Commission of Scientific Research Projects despite 10 actigraphy devices in demand. Owing to the lack of actigraphy devices, the duration of one month follow-up and the lack of patients during the dates of the experiment, the study has been carried out notwithstanding of the power analysis to be carried out for sample size.

\section{Conclusion}

As a consequence, it has been found out that although phototherapy have not affected the daily activity intensity, it has increased daily activities and sleep duration. Accordingly, the application of phototherapy among non-pharmacologic methods is of much importance in terms of regulating daily activities and sleep pattern of the patients. Healthcare professionals should be informed and encouraged about this application.

Papers: The only main findings of the study are verbally identifying IGGC 2017 Spain.

\section{Ethics}

Ethics Committee Approval: The study was approved by the Clinical Research Ethics Committee of ESOGU Faculty of Medicine (06.06 dated 18-05-2016).

Informed Consent: Informed consent was obtained from all patients/relatives (due to Alzheimer's disease) included in our study.

Peer-review: Internally peer-reviewed.

\section{Authorship Contributions}

Surgical and Medical Practices: G.B.A., A.Ö., Concept: G.B.A., A.Ö., D.Ö., Design: G.B.A., A.Ö., D.Ö., E.Ç., Data Collection or Processing: G.B.A., A.Ö., D.Ö., E.Ç., Analysis or Interpretation: G.B.A., A.Ö., D.Ö., E.Ç., Literature Search: G.B.A., A.Ö., Writing: G.B.A., A.Ö., D.Ö., E.Ç.

Conflict of Interest: No conflict of interest was declared by the authors.

Financial Disclosure: The authors declared that this study received no financial support.

\section{References}

1. Alzheimer's Association National Plan Milestone Workgroup, Fargo KN, Aisen P, Albert M, Au R, Corrada MM, DeKosky S, Drachman D, Fillit H, Gitlin L, Haas M, Herrup K, Kawas C, Khachaturian AS, Khachaturian ZS, Klunk W, Knopman D, Kukull WA, Lamb B, Logsdon RG, Maruff P, Mesulam M, Mobley W, Mohs R, Morgan D, Nixon RA, Paul S, Petersen R, Plassman B, Potter W, Reiman E, Reisberg B, Sano M, Schindler R, Schneider LS, Snyder PJ, Sperling RA, Yaffe K, Bain LJ, Thies WH, Carrillo MC. 2014 report on the milestones fort he US National Plan to Address Alzheimer's Disease. Alzheimers Dement 2014; 10:430-52.

2. The Healthy Brain Initiative: The Public Health Road Map for State and National Partnerships, 2013-2018. http://www.cdc.gov/aging/ pdf/2013-healthy-brain-initiative.pdf.avaible:18.02.2015.

3. Wilson RS, Schneider JA, Beckett LA, Evans DA, Bennett DA. Progression of gait disorder and rigidity and risk of death in older persons. Neurology 2002;58:1815-9.

4. Akdemir N. Sık Görülen Nörolojik Hastalıklar ve Hemşirelik Bakımı. 2. Baskı Sistem Ofset, Ankara, 2004:840-1.

5. Birol L. Hemşirelik Süreci. Hemşirelik Bakımında Sistematik Yaklaşım. Genişletilmiş 6.Basım, Etki Matbaaacılık, İzmir, 2005:15.

6. Karadakovan, A, Eti Aslan F. Dahili ve Cerrahi Hastalıklarda Bakım. 2.Baskı. Nobel Tıp Kitabevi, 2011. 
7. Benedict C, Byberg L, Cedernaes J, Hogenkamp PS, Giedratis V, Kilander L, Lind L, Lannfelt L, Schiöth HB. Self reported sleep disturbance is associated with Alzheimer's disease risk in men. Alzheimers Dement 2014;1:1090-7.

8. Hahn EA, Wang HX, Andel R, Fratiglioni L. A Change in Sleep Pattern may predict Alzheimer disease. Am J Geriatr Psychiatry 2014;22:1262-71.

9. Mccury SM, Reynolds CF, Ancoli-Israel S, Teri L, Vitiello MV. Treatment of sellep disturbance in Alzheimer's disease. Sleep Med Rev 2000;4:603-28.

10. Sloane PD, Williams CS, Mitchell CM, Preisser JS, Wood W, Barrick AL, Hickman SE, Gill KS, Connell BR, Edinger J, Zimmerman S. High-Intensity Enviromental Light in Dementia: Effect on Sleep and Activity. J Am Geriatr Soc 2007;55:1524-33.

11. Gammack JK. Light Therapy for Insomnia in Older Adults. Clin Geriatr Med 2008;24, 134-49.

12. Erdinç O, Tuncel D, Aslan K, Demir CF. Sirkadyen ritim uyku uyanıklık bozuklukları, Uyku Bozukluklarında Tedavi Rehberi. 2014:56

13. Akyar I, Akdemir, N. The effect of light therapy on the sleep quality of the elderly: An intervention study. Australian Journal of Advanced Nursing 2014;31:31-8.

14. Galli PF, Terman M, Reme CE, Raferty B, Terman JS, Burde RM. Ophthalmologic examination of patients with seasonal affective disorder, before and after bright light therapy. Am J Opthalmol 1995;119:202-10.

15. Labbate LA, Lefer B, Thibault A, Sachs GS. Side effects induced by bright light treatment for seasonal affective disorder. J Clin Psychiatry 1994;55:189-91.

16. Ertan P, Alkan S. Çocukluk çağında aktigrafi kullanımı. Türkiye Çocuk Hast Derg 2012;6:59-64.

17. Ancoli-Israel S, Cole R, Alessi C, Chambers M, Moorcroft W, Pollak CP. The role of actigraphy in the study of sleep and circadian rhythms. Sleep 2003;26:342-92.
18. Sun JL, Wu SC, Chang LI, Chiou JF, Chou PL, Lin CC. The relationship between light exposure and sleep, fatigue, and depression in cancer outpatients: test of the mediating effect. Cancer Nurs 2014;37:382-90.

19. Figueiro MG, Plitnick BA, Lok $A$, Jones GE, Higgins $P$, Hornick TR, Rea MS. Tailored lighting intervention improves measures of sleep, depression, and agitation in persons with Alzheimer's diseases. Clin Interv Aging 2014;9:1527-37.

20. Ho SC, Wong TK, Tang PL, Pang SM. Nonpharmacologic Sleep Promotion: Bright Light Exposure. Complement Ther Nurs Midwifery 2002;8:130-5.

21. Fullspectrumsolutions.avaible:http://www.fullspectrumsolutions. com/ultralux_v_bliv.htm,erişim:14.02.2015,http:// www.fullspectrumsolutionscom/light_boxes_55_ctg. htm:erişim:14.02.2015.

22. Van der Ploeg ES, O'Connor DW. Methodological challenges in studies of bright light therapy to treat sleep disorders in nursing home residents with dementia. Psychiatry Clin Neurosci 2014;68:777-84.

23. Forbes D, Blake CM, Thiessen EJ, Peacock S, Hawranik P. Light therapy for improving cognition, activities of daily living, sleep, challenging behaviour, and psychiatric disturbances in dementia. Cochrane Database Syst Rev 2014:CD003946.

24. Dowling G, Burr RL, Van Someren EJ, Hubbard EM, Luxenberg JS, Mastick J, Cooper BA. Melatonin and Bright-Light Treatment for Rest-Activity Disruption in Institutionalized Patients with Alzheimer's Disease. J Am Geriatr Soc 2008;56:239-46.

25. Burns A, Allen $H$, Tomenson B, Duignan D, Byrne J. Bright light therapy for agitation in dementia: A randomized controlled trial. Int Psychogeriatr 2009;21:711-21.

26. Riemersma-van der Lek RF, Swaab DF, Twisk J, Hol EM, Hoogendijk W], Van Someren EJ. Effect of bright light and melatonin on cognitive and noncognitive function in elderly residents of group care facilities: A randomized controlled trial. JAMA 2008;299:2642-55. 